\title{
A conceptual framework to understand student volunteerism
}

\author{
Jorge Cunha (Corresponding author)
}

ALGORITMI Research Center, University of Minho, Guimarães, Portugal

Postal address: Campus de Azurém, 4800-058 Guimarães, Portugal

Telephone number: +351253510768

Email: jscunha@dps.uminho.pt

ORCID identifier: 0000-0002-6267-708X

\section{Rainer Mensing}

International Business Administration, University of Twente, Enschede, The

Netherlands

Postal address: Drienerlolaan 9, 7522 NP Enschede the Netherlands

T:+49 15787904558

Email: rainer.mensing@hotmail.de

ORCID identifier: https://orcid.org/0000-0002-7474-1755

\section{Paul Benneworth}

Center for Higher Education Policy Studies (CHEPS), University of Twente, Enschede, The Netherlands

Agder Research, Norway

Postal address: Drienerlolaan 9, 7522 NP Enschede the Netherlands

Gimlemoen 19, 4630 Kristiansand S, Norway

Telephone number: + 31534893271

Email: p.benneworth@utwente.nl

ORCID identifier: orcid.org/0000-0003-0539-235X

\section{Acknowledgements}

An earlier version of this paper was presented at the European Higher Education Society conference in Porto, Portugal, September 2017. This work has been supported by COMPETE: POCI-01-0145-FEDER-007043 and FCT - Fundação para a Ciência e Tecnologia within the Project Scope: UID/CEC/00319/2013. The work was also undertaken as part of the "Crossing Borders" First Cycle Minor programme at the University of Twente. The authors would like to thank the host organisation and the interviewees for their candid responses. Any errors or omissions remain the responsibilities of the authors. 


\section{A conceptual framework to understand student volunteerism}

This paper develops a conceptual framework to understand the value of an increasing number of university study programmes that send students to the global south by learning through volunteering. We ask the research question what determines the benefit that these activities bring to the host community. To understand this, we conceptualise these activities as student volunteerism and propose a framework to understand the value of these activities based on a previously developed framework for volunteer tourism. We examine our research question using a single case study of a Minor programme in a Dutch university, exploring how course design and student selection affect student behaviour as an antecedent step to creating student benefits. We identify six kinds of factors that appear to promote 'deeper' (better) contributions and argue that these six factors require further analysis to better realise university contributions to societal development in Global South contexts.

Keywords: Student Volunteerism; Academic volunteering; Global south; Sustainable development; University engagement; Knowledge society

\section{Introduction}

Student Volunteerism is a phenomenon seeing students undertake volunteering projects to help less successful communities. It is not a novel phenomenon and has a long pedigree in degrees within subjects as diverse as Development Studies, Social Entrepreneurship or Tropical Medicine. These projects have as their pedagogic aim to provide students with a practical experience of applying their acquired theoretical knowledge in different contexts-of-application (Gibbons et al, 1994), thereby learning application skills which may also be useful in their wider careers. The notion of "volunteering" intuitively implies an activity that is intrinsically altruistic and beneficial (Carpenter \& Myers, 2007, Rehberg, 2005). However, 'international volunteerism' has latterly been the subject of debate as to whether it is indeed as universally beneficial as this framing may present it, particularly with the rise of commercial organisations 
arranging volunteer placements (Guttentag, 2011). Criticism has in particular focused on the imbalance of benefits between beneficiary community, intermediary organisation and volunteer student, and in particular skewing of benefits towards the latter (Barkham, 2006; Brodie, 2006; Popham, 2015).

Although the context of student volunteerism does differ slightly from volunteer tourism, we contend that these criticisms of international volunteering might also be applicable to some degree to student volunteerism. Callahan and Thomas (2005) distinguished volunteer tourism in terms of the volunteer projects' relative depth in terms of the extent to which it was altruistic, idealistic, and impact led; conversely they characterise 'shallow' activities as being profit-driven, opportunistic and ego-centric. The large volume of recent research on international volunteerism has generated substantive understanding of volunteers' motivations and decision frameworks (e.g. Lupoli, Morse, Bailey \& Schelhas, 2014, Lyons, Hanley, Wearing, \& Neil, 2012, McGehee, 2014, Sin, 2009, Taplin, Dredge \& Scherrer, 2014, Wearing \& McGehee, 2013, Zahra \& McGehee, 2013,). But little of this research has been applied to student volunteering and with the growing volume of universities promoting student volunteerism (inter alia Cnaan et al, 2010; Holdsworth \& Quinn, 2010), we contend there is value in applying insights from volunteer tourism literature to understanding the positive and negative aspects of student volunteerism. In particular, we argue that universities should seek to design their courses to recruit and equip students to work in a deep way as the best way to optimise the depth of these eventual outcomes.

In this paper we therefore seek to understand what can be done in terms of the design of a student volunteering course to maximise eventual impact, and ask the overall research question of what determines the 'depth' of student volunteering? We conceptualise 
student volunteerism by transposing Callahan \& Thomas's (2005) volunteer tourism literature to the academic domain, and address the research question using a single case study of a student volunteerism activity in Kenya operated by a Dutch technical university. The study involved a mix of non-participant observation and formal interviews, and we analyse the ways that the program construction influences participants' behavioural choices in terms of their 'depth', with altruistic intentions, knowledge, skills and resources to contribute to a project. On this basis we are able to identify characteristics of students and courses that will maximise the depth of student volunteerism activities. There are here three factors that influence this depth, (a) the course is relevant to their professional// academic development (b) students are active in seeking hosts and developing projects and (c) students carefully reflect on the project's sustainability during their course.

\section{Understanding different kinds of volunteering}

\section{Conceptualising international volunteer tourism}

International volunteerism has arisen in the context of more general concern to drive progress towards sustainable development attempts, with individuals seeking to contribute and serve communities in need through volunteering for humanitarian and environmental projects (Wearing \& McGehee, 2013). In this context, volunteering projects are typically related to community welfare activities, environmental conservation and research, education, construction, business development and healthcare (Guttentag, 2009). One of the key perspectives that emerged within international volunteerism studies was the idea of volunteer tourism, defined here by Sin as 'a form of tourism where the tourists volunteer in local communities as part of his or her travel' (Sin, 2009, p. 480). Barbieri, Santos and Katsube (2012, p. 510) 
characterise international volunteer tourism as encompassing 'the leisure and recreation component associated with tourism, along with the desire to contribute to solving deep social illnesses such as poverty, gender inequality, and parentless childhood'.

Within this overall phenomenon, a number of key distinctions can be made between different categories of international volunteer tourists based on their motivations for volunteering and the degree of importance they attach to benefiting the local community benefit (Chen \& Chen, 2011). Wearing and McGehee (2013, p. 122) noted that the reasons for which a volunteer chooses to travel may differ from other kinds of tourist, and three kinds of volunteer tourist can be distinguished.

One kind of volunteer is one primarily interested in the travel element (volunteer vacationers): Brown (2005), for example examined the 'motivational factors of volunteer tourism from the perspectives of vacationers who spend a small proportion of their trip volunteering at the destination' (p. 492). The author concluded that volunteer vacationers are primarily interested in the opportunities that volunteering brings in educating children, bonding with family members, and in delivering camaraderie. Brown argued that these volunteers seem to be driven by a sense of adventure and desires for exploration and novelty; strongly motivated by factors such as love and social needs alongside their learning needs. Sin (2009) found that 'at least among those interviewed, motivating factors for volunteer tourists were "to travel" rather than "to contribute"' or volunteer' (p. 497). Likewise, a number of comparable studies (inter alia Barkham, 2006; Mcgloin \& Georgeou, 2015; Wearing \& McGehee, 2013) identified that the volunteers did not primarily have altruistic intentions, but were motivated by a desire of self-gratification, self-development, adventure, cultural understanding, or being able to claim the experience on the resume. Nevertheless, within this group, a 
distinction can be made between those that tend to be principally volunteer-minded and those who are vacation-minded (Smith \& Holmes 2009):

A second category of international volunteer tourists are commercial volunteers (Coghlan \& Noakes, 2012, Guttentag, 2012, Guttentag, 2009), those that pay an agent to arrange a volunteering holiday. The agent in this case may be drawn from a wide range of organisations, such as private companies, not-for-profit organisations, charities, and universities, and themselves have a wide range of motivates (Guttentag, 2009). As emphasised by McGehee (2014, p. 847), 'Volunteer tourism activities have expanded from a few little-known (and primarily nongovernmental) organizations to a multitude of entities ... from full nonprofits to openly for-profit ventures'. Contemporary commercial volunteer tourism projects are primarily promoted by commercial for-profit business firms based in a developed country, rather than a developing country where most of the volunteering occurs (Coghlan \& Noakes, 2012). These projects emphasise both volunteering and vacation, but because the activities cost more than a standard holiday alone, the volunteers themselves tend to have more altruistic motivations than the touristic volunteers. At the same time, the commercial focus of agents leads often to relatively low requirements for participants' skills allowing for a mismatch between volunteers' expectations and the local hosting community's needs (Guttentag, 2012).

A class of volunteer is those undertaking volunteer vacations, defined by Brown and Morrison (2003, p. 73) as " giving time and energy for a good cause and paying for the privilege'. In these activities, volunteering is the primary reason to travel and the main activity undertaken at the destination (Smith \& Holmes, 2009). There is a trend of increasing volunteer numbers for projects that require particular skill sets to deliver scientific, ecological, social service, or other project types, often regarded as more directly related to contributing to international development (Holmes, Smith, 
Lockstone-Binney \& Baum, 2010). Project focus lies primarily on service delivery, offering at the same time travel and adventure experiences for short-term periods (Brown \& Morrison, 2003). Brown and Morrison (2003) identified certain characteristics associated with a propensity to participate in volunteer vacations: volunteering in one's home community, higher education level, frequency of vacations and higher household incomes. One specific variant is Gap Year Volunteering between secondary and tertiary education: Lyons et al. (2012, p. 361) argue that 'the valorisation of cross-cultural understanding and promotion of an ethic of global citizenship are at the forefront of the recent development and proliferation of international "gap year" travel programs and policies'.

This typology between volunteers and the likely quality of the project, with the assumption that a greater volunteer concern for the local community leads to more positive outcomes. But we contend that a better typology could be made on the basis of the realised benefits (and potentially disbenefits) in hosting communities (e.g. Barbieri et al., 2012, Guttentag, 2009, Hammersley, 2014). Indeed, Guttentag (2009) summarizes several potential negative characteristics from well-intended but badly implemented volunteer tourism:

- neglecting locals' desires;

- hindering or undermining work-in- progress or delivering unsatisfactory work;

- displacing local workers and employment opportunities,

- reinforcing dependency cultures \& reinforcing 'othering' between volunteer and host, and

- potential cultural change.

Conversely, McGehee (2014) noted that well designed and implemented international volunteerism projects offer opportunities for 'altruism, self-development, giving back to the host community, participating in community and international development, and improving cultural understanding' (p. 848). 


\section{Towards a framework for Student Volunteerism}

Callahan and Thomas (2005) proposed a framework for volunteer tourism which distinguished successful projects in terms of two dimensions of what made a project successful, namely volunteer characteristics as well as the projects' relation to the local community. They characterise the altruistic orientation (volunteers, delivering change) as representing 'deep' volunteer tourism, and the selfish orientation (vacationers, recruiting customers) as 'shallow' volunteer tourism. 'Deep' projects and/or volunteers are altruistic, idealistic and with a focus on making an impact, whilst 'shallow' projects/ volunteers are profit-driven, opportunistic and with a selfish approach. We contend that distinguishing deep and shallow students and projects is useful for considering what can be done to improve the courses (educational placements) that create student volunteers. We are here primarily concerned with the power imbalance between student/ tourist and the local community and the risks that arise with the student being more powerful in various ways than the local community, and also less committed to the outcomes of the project. Indeed, one of the issues stimulating our research was our prior experience with a student volunteering cohort that there was indeed a tendency amongst students to treat the placement as either a holiday or a serious duty. At the same time, we acknowledge that there may be imbalances of power where the student is the exploited party, either by an intermediary or the local community, because of the students' dependence upon completing the task to gain study credits. This would represent for us a breach of the duty of care of university towards their students and represent a fundamental failure of educational responsibility, and we feel that the subject would deserve its own specific treatment outwith the framework of a paper that is primarily dealing with the risks of pedagogic opportunism. 
We transpose Callahan and Thomas's (2005) model to the Student Volunteerism context for both projects and student characteristics using the six factors they define as determining the relative depth of volunteering. The six factors determining project depth are:

(a) Duration of placement (longer placements drive deeper activities)

(b) Choice of destination (being driven by good cause drives depth)

(c) Idealism of participants (higher idealism is associated with higher depth

(d) Skill relevance (selection mechanisms which target relevant skills improve depth)

(e) Pro-social orientation (the more the project involves planning creating impact, the deeper the activity).

(f) Local involvement (the more local actors are involved in co-determining the activities the greater the depth of activity).

The six volunteer factors determining the depth of volunteering are:

(a) Duration of participation permitted by the academic course

(b) Choice of destination and the extent to which students are forced to take available projects or select their own destination

(c) Idealism (the value the participant places on making a local contribution)

(d) Skills fit (whether the individual is selected on the basis of their skills' relevance to available projects)

(e) The willingness and capacity of student to involve host community in project design

(f) The willingness and capacity of student to involve host community in project implementation 
These potential characteristics are summarised in Table 1, and justified briefly below. In terms of duration, placements that are driven by the delivery of a task would appear to be allow deeper placements than those driven by minimum project length requirements for module accreditation. Where destination choice is driven by the availability of projects would suggest deeper behaviours than those driven by popular projects or locations. Selecting those students who are seeking to contribute to their hosts' contexts would be deeper than those who are seeking to maximise their personal experience. Likewise selecting students in terms of the relevance of their skill set to the project, and their pro-social orientation would raise depth of engagement. Finally, developing longterm ongoing relations with local representatives allowing them to shape the way the projects are presented to students would also increase the depth of behaviour.

Table 1 Student Volunteerism Programmes determining characteristics

\begin{tabular}{|l|l|l|}
\hline & Volunteer Tourists & Student Volunteerism \\
\hline $\begin{array}{l}\text { Duration of } \\
\text { participation }\end{array}$ & $\begin{array}{l}\text { Flexibility in excursion length } \\
\text { Flexibility in terms of work } \\
\text { commitment on site }\end{array}$ & $\begin{array}{l}\text { Occupation with assignments of } \\
\text { low value to organization }\end{array}$ \\
\hline $\begin{array}{l}\text { Choice of } \\
\text { destination }\end{array}$ & $\begin{array}{l}\text { Level of focus on regional } \\
\text { characteristics vs. on project } \\
\text { characteristics }\end{array}$ & $\begin{array}{l}\text { Level of focus on popular vs. } \\
\text { practical project types }\end{array}$ \\
\hline $\begin{array}{l}\text { Targeting } \\
\text { idealists }\end{array}$ & $\begin{array}{l}\text { Trade-off; volunteer vs. host } \\
\text { interests }\end{array}$ & $\begin{array}{l}\text { Focus on impact on host vs. impact } \\
\text { on student } \\
\text { Flexibility in host choice }\end{array}$ \\
\hline $\begin{array}{l}\text { Participant } \\
\text { skills }\end{array}$ & $\begin{array}{l}\text { Level of qualifications needed } \\
\text { Depth of preparation and } \\
\text { evaluation }\end{array}$ & Selection Process \\
\hline $\begin{array}{l}\text { Pro-social } \\
\text { orientation }\end{array}$ & $\begin{array}{l}\text { Level of individual volunteers } \\
\text { added value to the organization } \\
\text { Ratio of "Give vs Take" }\end{array}$ & $\begin{array}{l}\text { Level of involvement in project } \\
\text { design }\end{array}$ \\
\hline $\begin{array}{l}\text { Local } \\
\text { involvement }\end{array}$ & $\begin{array}{l}\text { Depth of agent/ host relationship } \\
\text { Involvement of host in project } \\
\text { design, selection and planning } \\
\text { Level of general risk awareness } \\
\text { and mitigation of negative } \\
\text { impacts }\end{array}$ & $\begin{array}{l}\text { Local interests representation in } \\
\text { students assignment structure }\end{array}$ \\
\hline
\end{tabular}


We contend that these various elements are sequentially arranged in a student volunteerism context through which the benefits (or disbenefits) emerge; firstly courses are designed, then students are recruited, and finally hosts receive a placement activity. On the basis of Table 1 above, we propose that deeper courses (offering longer placements on the basis of existing projects, targeting students who are idealists with project-relevant skills, and allowing community involvement in project design and execution) will attract 'deeper' student volunteers. Deeper student volunteers (who work for longer on useful projects, with altruistic orientation and relevant skills, and a willingness and capacity to allow local community influence in project design and execution) will in turn be associated with more beneficial outcomes, and ultimately with the delivery of societal benefit. This is shown in Figure 1 below.

Figure 1: Our argumentation frame, conceptual framework and research question

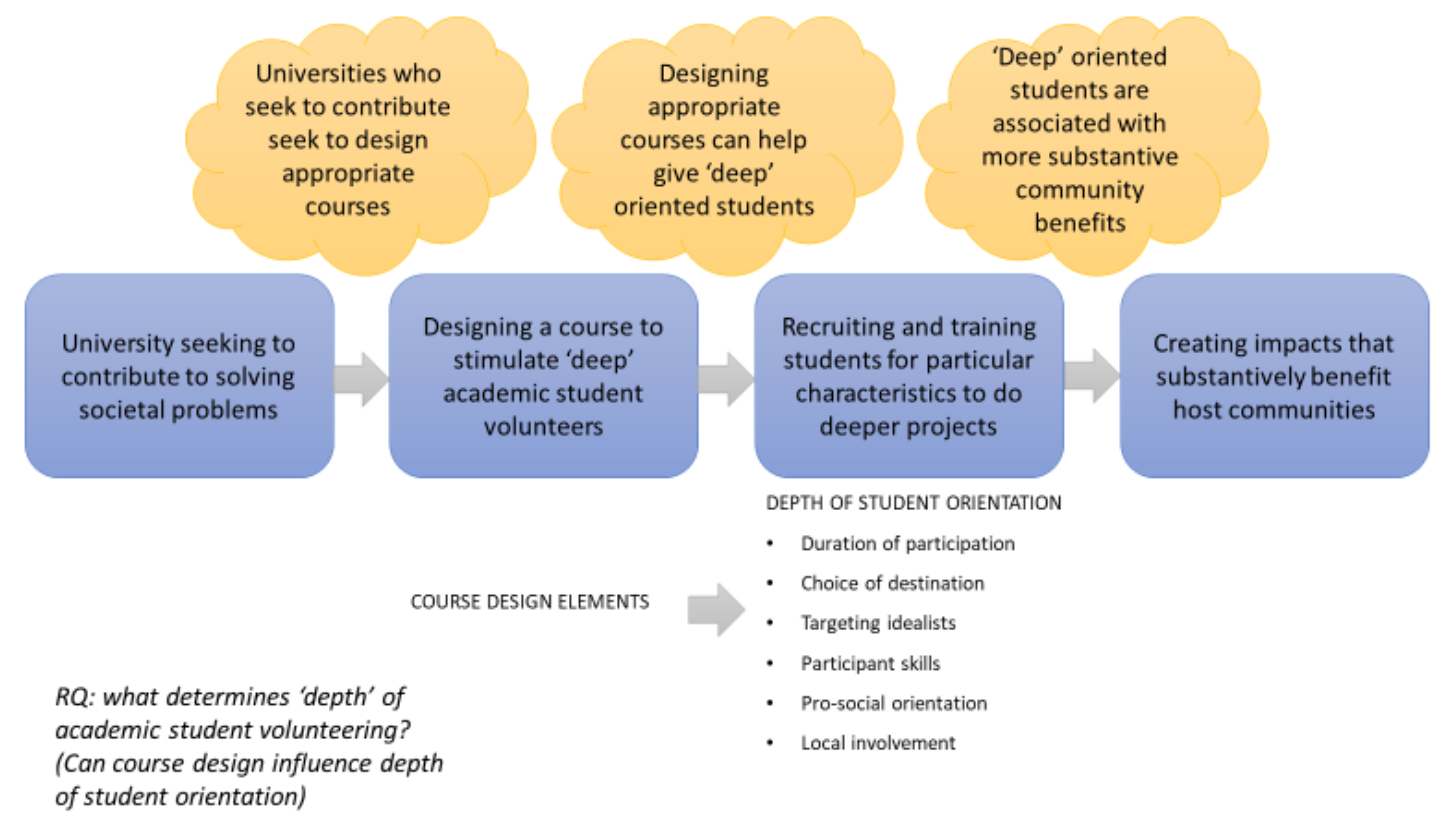

Source: authors' own design 
Our overall research question in this paper is what determines the depth of student volunteering? Although there will always be conditions under which a shallow student produces a deep outcome, our argument is that in general, more depth in students will produce more depth in outcomes, and therefore if universities wish to produce ceteris paribus deeper outcomes (bigger community impacts) then they should target recruiting students with 'deeper profiles'. Our operational research question then is to consider the relationship between the first of these steps, between course design and student orientation, asking “does designing 'deeper' student volunteerism activities lead to the attraction of 'deeper' student volunteers?"

\section{Research methodology}

This research question is premised upon a transposition of the volunteer tourism framework to a cognate domain, student volunteerism, without validating that transformation. The research design is therefore explicitly exploratory, exploring the framework's applicability as much as the associations between the variables in our causal chain (the course design, the student/ project match and the host community impact). We therefore chose a qualitative approach considering course and student characteristics, and through interviewing and participant observation exploring whether course design appears to have influenced student characteristics (see Figure 1). We do not claim a universality for our findings, but instead seek to iterate our initial student volunteerism framework as proposed in Table 1, and contribute to helping understand what universities can do to ensure that their student volunteering operates beneficially for recipient communities.

Our case study is of a single programme, an undergraduate Minor course that sends undergraduate students to volunteer in the global south. A minor course in the 
European context is an option (or requirement) for students that they take a course from outside their primary study focus; they may take modules within other degree programmes or they may be created specifically as stand-alone units to allow students to meet Minor requirements. Minor volunteering courses typically mix a preparatory phase with an execution phase; this execution phase may take the form of a study trip, it may be delivered virtually, or it may be delivered in situ; it is this last form of volunteering with which we are concerned, following Callahan \& Thomas's observation that a number of months are necessary for the project to have a depth antecedent to societal value. The Minor programme we selected sends students to work on preallocated projects, and the case study involved activities centred around a community centre project in a rural Kenyan village. The community centre was to empower the local community with a strong focus on the young people. The particular project was associated with the promotion and fostering of social entrepreneurship and social sustainable development in the hosting community. In this project, four undergraduates participated, and had to support to set up new initiatives for the community centre and to make the centre overall self-sufficient. The four students eventually, with the help of partners, proposed to implement a bamboo bike rack to enable the villagers to transport more goods more quickly, as alternative to carrying it on their heads. The rack was to be produced in the community centre and then sold at a profit to generate income.

There were three elements to the data gathering. Firstly, data was gathered from material produced by the sending university on the Minor course itself, to understand the choices made in terms of the course structure and the Minor's intentions for the students. This was complemented by interviewing the Module coordinators of the corresponding Minor programme (using Skype, one interview lasting one hour) to provide further insight into the structure, design and intentionality of the Minor 
Programme. The semi-structured interview guide was largely based on the factors presented in the adapted Callahan and Thomas (2005) framework, and was organized in three sections. In the first section, the respondents were asked to introduce the Minors historical background and the reasons for its establishment, in order to obtain first insights into goals and objectives of the Minor in a broader sense. The second section focused on more technical and methodological details of the Minor, namely about the selection, preparation, supervision and evaluation process. The third section inquired about negative experiences and the Minors responses to it. The questions tried to extract the respondents' knowledge about common negative effects of International Volunteerism both on host and volunteer.

The other element of data gathered was participant observation. The choice of resorting to participant observation (via unobtrusive observations without interviewing directly students) was justified by the fact that a longer research time period allowed to obtain more detailed and accurate information about the students' behaviour under study and, at the same time, to avoid manipulation and bias in the behaviour of observed students. The duration of the observation period comprised eleven weeks: begun on 7 th of November, 2016, and ended on the 21st of January, 2017. The fieldwork was gathered in a period in which the researcher was located within and working on the project (as a student participating in a different Student Volunteering programme). The researcher was therefore interacting with these student volunteers and was able to observe and interpret the various characteristics suggestive of depth or shallowness, and the ways in which the participants related them to the requirements imposed by the course. The researcher was also able to observe the degree of local involvement in the design and the execution of the project, and the ways in which local hosts were able to steer the activities towards deeper ends. Particular care was taken with the ethical 
aspects of this project, relating to the involvement of human subjects in the research; care was taken not to judge or evaluate individual participants, but rather to record the stories that the volunteers told about how the course requirements had shaped the depth of their own participation. The 'Guidelines for Ethical Conduct in Participant Observation' (SSH REB, 2005) were followed as the framework for the fieldwork, and particular care was taken prior to the research visit to emphasise the importance of these ethical considerations. All data was therefore stored in anonymous and confidential form (omitting information on student, host organisation, university, minor, major or gender), and the case study is presented in a synthetic anonymised way in order to protect the research subjects interest.

\section{Characterising the depth of the course}

The case study Minor Programme was established in the early 2000s to offer students the opportunity to include global development issues within their graduation dissertation projects, something highlighted by student and alumni consultations as missing at the time. In response to this feedback, a group of teachers with a background on entrepreneurship in development countries developed the specific Minor programme, focusing on social entrepreneurship rather than a more general service delivery As the Module Coordinator said in interview, they were looking for projects for the minor that had an "entrepreneurial character, so it is not service delivery to help in the short term... but that capacity is built to deal with problems in (...) organizations", with the overall goal of the module being to "to build up expertise for technology transfer to developing countries".

Students were recruited by an application process that involved students sending a motivation letter explaining their interest in the particular learning opportunities 
offered in the module, which was evaluated along with their prior grades. Each year saw 110-120 applications with the module coordinators selecting the best 60 to follow the module. Students selected for participation were then matched with projects proposed to the Module Team via a 'project fayre'; projects each presented to students, the students then ranked projects in terms of their own preferences and based on those rankings were allocated into groups comprising 2-4 students. Projects then followed three steps. In the preparatory phase, the student groups designed a project in collaboration with the host, as well as taking preparatory courses. The second phase was execution; students delivered the project in the field under local supervision, with a high degree of variation in approaches and intensity. The final step was evaluation via the marking of the final report. In the final phase, the students' projects are evaluated via final report.

Table 2 (below) characterises the course design in terms of its depth following the six variables of our conceptual framework. The course's construction showed both deep and shallow characteristics; there was a high degree of opportunism in how students were allocated to projects, and projects were allocated on an availability basis (often where previous groups had been sent) leaving no opportunity to match up projects and student team skills. The university did seek to select highly motivated students through its recruitment procedures (a course limit is rather rare in the Dutch context), and the long-term nature of relationships between the Minor Coordinators and projects helped to build up understanding of local partners' requirements. This mix of depth and shallowness was also reflected in the student behaviour, with the most important drivers of depth of behaviour being (perhaps unsurprisingly) placement length along with student flexibility to negotiate and change the direction of the project to reflect local circumstances. What drove shallow behaviour tended to be the lack of 
difficulty in choosing the minor course, which would be associated with more self-

interested rather than altruistic behaviour from the students mitigated towards seeing the experience as being useful. This characterisation of the designed depth of the programme are summarised in Table 2.

Table 2 - The designed depth apparently in the programme characteristics.

\begin{tabular}{|c|c|c|}
\hline Factor & Shallow Characteristics & Deep Characteristics \\
\hline $\begin{array}{ll}\text { Flexibility } & \text { in } \\
\text { duration } & \text { of } \\
\text { participants } & \end{array}$ & & $\begin{array}{l}\text { Strong focus on specific project type } \\
\text { Little flexibility in terms of options/ } \\
\text { alternative host } \\
\text { A lot of flexibility in terms of assignments }\end{array}$ \\
\hline $\begin{array}{l}\text { Promotion of } \\
\text { project v. the } \\
\text { destination }\end{array}$ & $\begin{array}{l}\text { Descriptions do not ask for specific skills } \\
\text { Selection based on volunteers preference }\end{array}$ & $\begin{array}{l}\text { Focus on the project and its host } \\
\text { organization }\end{array}$ \\
\hline $\begin{array}{l}\text { Altruistic v. self- } \\
\text { interest }\end{array}$ & $\begin{array}{l}\text { Selection not too strict } \\
\text { Still quite a lot of places }(60) \\
\text { Participation in groups }\end{array}$ & $\begin{array}{l}\text { Idealistic underlying Idea \& Mission and } \\
\text { Balanced focus on student and host } \\
\text { Selection Process }\end{array}$ \\
\hline $\begin{array}{l}\text { Skills } \\
\text { participants }\end{array}$ & $\begin{array}{l}\text { Assignment to project not based on } \\
\text { students' individual skills } \\
\text { Evaluation not very intensive }\end{array}$ & $\begin{array}{l}\text { Selection based on students' motivation/ } \\
\text { commitment } \\
\text { A portfolio of courses directly relevant for } \\
\text { projects/ excursion } \\
\text { Integration of evaluative component in final } \\
\text { projects }\end{array}$ \\
\hline $\begin{array}{l}\text { Active/Passive } \\
\text { participation }\end{array}$ & $\begin{array}{l}\text { No proactive mitigation based on research } \\
\text { (No coordination between students/ local } \\
\text { partner prior to excursion) }\end{array}$ & $\begin{array}{l}\text { Active selection and evaluation of hosts and } \\
\text { students } \\
\text { Engagement of students to improve projects } \\
\text { and to cooperate with the project partner } \\
\text { Risk mitigation through interventions }\end{array}$ \\
\hline $\begin{array}{ll}\text { Level } & \text { of } \\
\text { contribution } & \text { to } \\
\text { locals } & \end{array}$ & $\begin{array}{l}\text { Host not involved in student selection } \\
\text { Hosts influence on project design indirect }\end{array}$ & $\begin{array}{l}\text { Integration of the local interests in } \\
\text { curriculum and assignments } \\
\text { Desire for strong and long term agent-host } \\
\text { relationships }\end{array}$ \\
\hline
\end{tabular}

\section{Characterising student response to designed depth}

It is clear from the fieldwork that the planned intentions designed into the Module did not always directly correspond with student behaviour. Firstly, despite the effort placed by the module to foreground the good cause (through the use of the "project fayre" 
approach), the students were driven in making their choice of project between the good cause/ particular project, but also for the destination, in this case Kenya. The project had been designed to ensure that there was sufficient time allowed to make a contribution to the local community; the students were on site for three months, and the preparation phase had helped them to bond as a team, work efficiently and keep to their plans. But at the same time, the students had also planned their free time prior to travel, and therefore reported that they restricted their involvement to what was required by the project, and at the same time participated in tourist activities. The motivation letter had been intended to select students on the basis of altruism and prevent selfishness, and the students indeed reported having some desire to do good, to make a difference, and to be good people. At the same time, the participants revealed no inconsistency between creating a local benefit and ensuring their participation led to personal, experiential and professional benefit.

The team selected had a suitable skill set for carrying out the project, bringing together people with engineering, technical and business skills, and these fitted well with the project at hand. At the same time, the experience of the preparatory phase was reported by the students to be dominated by the excitement and anticipation of the coming travel. As a result, the elements of the course that related to 'making a difference', the preparatory courses and the evaluation of the deeper understanding, became peripheral in the module. The students were active in allowing the local organisation to shape the planning and execution of the project; notably, the project team changed the project plan in a substantive way during the planning phase. Likewise, there was effective co-operation between the project team and local hosts to ensure that the project, the piece of market research explained in section 3 above, was useful to the local host organisation. But at the same time, the students remained passive in the face 
of considerable inputs from the local hosts (who had been hosting these groups for several years), and students reported being less interested in activities which were not immediately eligible for assessment (such as the impact evaluation). These characteristics are summarised in Table 3.

Table 3 - Observed depth of student behaviour.

\begin{tabular}{|c|c|c|}
\hline Factors & Shallow Characteristics & Deep Characteristics \\
\hline $\begin{array}{l}\text { Importance of } \\
\text { the } \\
\text { destination }\end{array}$ & Desire for leisure and recreation & Medium enthusiasm for the project \\
\hline $\begin{array}{l}\text { Duration of } \\
\text { participation }\end{array}$ & $\begin{array}{l}\text { Taking many opportunities to enjoy } \\
\text { free time } \\
\text { Putting time into volunteering, but } \\
\text { only as much as needed. } \\
\text { Trading off work time for } \\
\text { recreation time rather than vice } \\
\text { versa }\end{array}$ & $\begin{array}{l}\text { Almost three month } \\
\text { Working efficiently } \\
\text { Good time planning and } \\
\text { commitment }\end{array}$ \\
\hline $\begin{array}{l}\text { Focus of } \\
\text { experience: } \\
\text { altruistic } v \text {. } \\
\text { self-interest }\end{array}$ & $\begin{array}{l}\text { Some extend of vacation centrism } \\
\text { Also personal and academic self- } \\
\text { development } \\
\text { Mostly desire to have a nice/unique } \\
\text { experience }\end{array}$ & $\begin{array}{l}\text { Some intentions to 'help'. } \\
\text { Comments about 'making a } \\
\text { difference' in students' online } \\
\text { profiles } \\
\text { Somewhat relevant for altruistic } \\
\text { self-development with one } \\
\text { participant }\end{array}$ \\
\hline $\begin{array}{l}\text { Skills/Qualific } \\
\text { ations of } \\
\text { participants }\end{array}$ & $\begin{array}{l}\text { Low engagement with preparatory } \\
\text { courses } \\
\text { Low active evaluation of } \\
\text { experiences or desire for deeper } \\
\text { understanding }\end{array}$ & $\begin{array}{l}\text { A broad skill set, with } \\
\text { qualifications suitable for the } \\
\text { project }\end{array}$ \\
\hline $\begin{array}{l}\text { Active/Passive } \\
\text { participation }\end{array}$ & $\begin{array}{l}\text { Largely passive choice of project or } \\
\text { even Minor itself } \\
\text { Largely Passive in providing } \\
\text { solutions when issues arose in the } \\
\text { organisation }\end{array}$ & $\begin{array}{l}\text { Active decision to pivot from } \\
\text { original project design }\end{array}$ \\
\hline $\begin{array}{l}\text { Level of local } \\
\text { contribution }\end{array}$ & $\begin{array}{l}\text { Significant amount of expert input, } \\
\text { yet little influence on decision } \\
\text { making for alternative project } \\
\text { Low stake in future of local } \\
\text { community } \\
\text { No serious interest in impact } \\
\text { evaluation }\end{array}$ & $\begin{array}{l}\text { Significant amount of Market } \\
\text { research. } \\
\text { Successful decision making based } \\
\text { on local expert input (original } \\
\text { project) }\end{array}$ \\
\hline
\end{tabular}




\section{Towards a framework for designing student volunteerism to promote deeply engaged students}

Drawing together the material presented in the two previous sections, it is possible to identify six ways in which the course design appears to play a role in determining the depth of student behaviour (see Table 4). The first was the 'mission' of the course activity and design in terms of how well specified the requirement was that the purpose of the course was to make a contribution to a host community. In our case, this mission originated from the coordination teams' roots in entrepreneurial education, in their approach which sought to equip students to make a difference by understanding how to identify opportunities, positively decide to make a difference, develop and implement a plan towards change. However, the practical context of the module left those elements intended to stimulate the students' entrepreneurial approach in effect peripheral to the module as the students became excited about their impending travel period.

The second and third factors relate to student selection, both direct and indirectly. Indirect selection occurs in the students that consider the module, and that is affected by the course reputation within the university. The fact that the module has existed for a decade means that students can undertake their own research and ask previous students what the real requirements of the module, where the emphasis lies and which course elements are essential and which elective. The reputation the course had for stringency and setting high standards is therefore likely to attract students more closely aligned with the aims of the course, in this case for depth of engagement. The second element was the direct selection of the students through the use of the motivation letter and on the basis of grades. The grades criterion was not a good selection, and the motivation letter was reported as having a degree of difficult in 
distinguishing between students who merely claimed a desire to make a contribution, and those with a genuine orientation to altruism.

The final set of elements related to the project based elements. The students reported that they took most seriously those preparation assignments that most strongly corresponded to the module's assessment requirements; this was exemplified by the fact that whilst the issue of practical entrepreneurship was intended to be foregrounded in the module but it instead became peripheral because of difficulties in assessing it. A second element here was the selection of projects by the Module coordinator, and in particular in selecting local hosts able to work well with the students. In the case under study, the students reported as being slightly overwhelmed by the pressure the very well configured placed them under to 'codetermine' the project as had already happened with previous cohorts. Finally, the risk mitigation capacities in the project were important, because every time an unexpected situation created a project crisis, it forced the students to concentrate on the primary task of delivering their learning objectives, relegating the importance of the project. Risk mitigation measures ensured the Module Coordinator and local hosts had a capacity to keep the students working towards an impactful outcome. These are summarised in the Table 4.

Table 4 - Student volunteerism design factors promoting local contributions.

\begin{tabular}{|c|c|c|c|}
\hline & High Impact & Intermediate Impact & Low/Negative Impact \\
\hline Mission & $\begin{array}{l}\text { Knowledge diffusion } \\
\text { AND } \\
\text { Promotion of sustainability } \\
\text { AND } \\
\text { Capacity Building in host and } \\
\text { student } \\
\text { Strong philosophy }\end{array}$ & $\begin{array}{l}\text { Knowledge diffusion } \\
\text { AND/OR } \\
\text { Promotion of sustainability } \\
\text { AND/OR } \\
\text { Capacity Building in host and } \\
\text { student } \\
\text { Some trade-off of impact }\end{array}$ & $\begin{array}{l}\text { No serious Mission } \\
\text { Strong student centrism }\end{array}$ \\
\hline $\begin{array}{l}\text { Minor } \\
\text { Reputation }\end{array}$ & 'Excellence and High Impact' & 'Making a difference' & 'Nice experience' \\
\hline Selection & $\begin{array}{l}\text { Tough selection of students } \\
\text { Strong Minor-Host relationships }\end{array}$ & $\begin{array}{l}\text { Some selection } \\
\text { Some relationships }\end{array}$ & $\begin{array}{l}\text { No selection } \\
\text { No relationships }\end{array}$ \\
\hline
\end{tabular}




\begin{tabular}{|l|l|l|l|}
\hline Preparation & $\begin{array}{l}\text { Strong connection between } \\
\text { theory and excursions }\end{array}$ & $\begin{array}{l}\text { Some connection between } \\
\text { theory and excursions }\end{array}$ & $\begin{array}{l}\text { No connection between } \\
\text { theory and excursions }\end{array}$ \\
\hline Supervisors & $\begin{array}{l}\text { Strong commitment to projects } \\
\text { Proactive supervision } \\
\text { Have relevant expertise }\end{array}$ & $\begin{array}{l}\text { Medium commitment } \\
\text { Active supervision } \\
\text { Have some expertise }\end{array}$ & $\begin{array}{l}\text { Low commitment } \\
\text { Passive supervision } \\
\text { Have no expertise }\end{array}$ \\
\hline $\begin{array}{l}\text { Risk } \\
\text { Mitigation }\end{array}$ & $\begin{array}{l}\text { Strong representation of local } \\
\text { interests in programme } \\
\text { Deep evaluation of experience } \\
\text { Proactive risk mitigation }\end{array}$ & $\begin{array}{l}\text { Medium representation of local } \\
\text { interest in programme } \\
\text { Evaluation of experience } \\
\text { Reactive risk mitigation }\end{array}$ & $\begin{array}{l}\text { No representation of local } \\
\text { interests in programme } \\
\text { No evaluation of } \\
\text { experience } \\
\text { Risk negligence }\end{array}$ \\
\hline
\end{tabular}

This is summarised in Figure 2 below.

Figure 2 Effects of course design on student orientation (depth of behaviour)

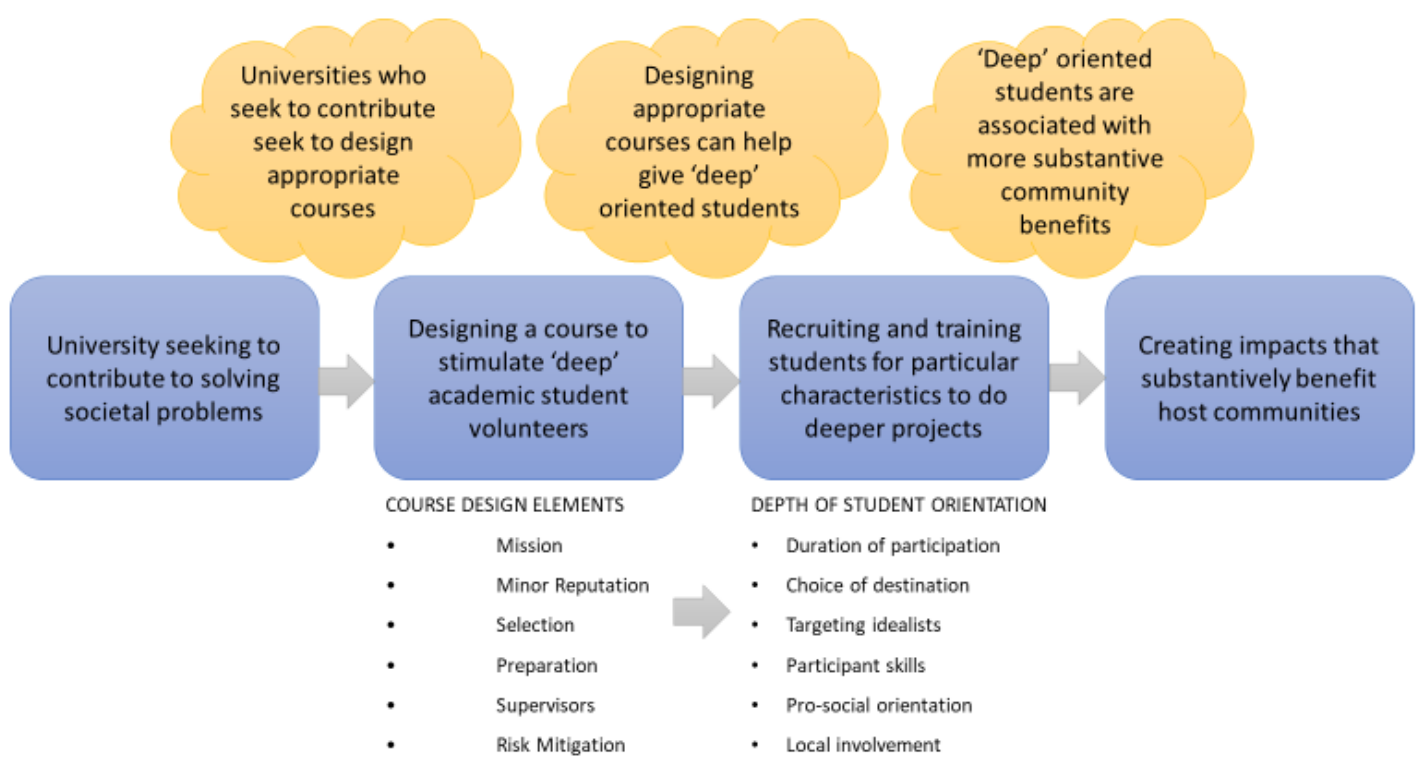

Source: authors' own design based on Figure 1

\section{Concluding Discussion}

Student volunteerism depends for its sustainability for both the hosting community and the student, while not becoming another form of tourism based mainly on the 'commodification of at least partly altruistic intent' (Wearing \& McGehee, 2013, p. 127). In this context, the framework proposed above is a potential tool to help improve the orientation of programmes to stimulate students to make a deeper contribution, or if that is not the desired aim, to place more emphasis on the individual learning and 
development activities. The case study demonstrates the extent to which international volunteering frameworks provide a means to understand how universities can meet their wider societal responsibilities by ensuring that their student placements in the global south maximise their potential contribute to wider processes of local development. This is particularly important in the context of rising expectations to contribute to processes of global development; all too often the emphasis here is reduced to unilaterally providing advanced knowledge and research skills for these places rather than contributing to locally-situated collective learning activities in which universities contribute to local developments as equal, not superior, partners. In the context of a relatively small piece of exploratory research, we therefore contend that our research, and the course design characteristics that contribute to student volunteering depth, provide a useful iteration of the conceptual model of how university student projects can contribute to societal development. By focusing on teaching rather than research or technology transfer, this approach broadens the view of activities by which universities contribute to societal development, and therefore extends contemporary debates about the roles of higher education in the knowledge society.

We acknowledge that this is an exploratory and tentative piece of research, and therefore must remain modest in drawing too many conclusions. Nevertheless, we are struck by the roles for universities and communities that this highlights, and the important of ensuring equivalence between the university and the community around the delivery of a common shared learning project, a learning project in which each partner (student and community) has their own individual urgent need in fulfilling. In understanding how universities can contribute more to societal development outside licenses, patents and spin-off companies, we therefore argue more attention need be paid to the role of student as a knowledge vector. Conceivably, the main contribution of this paper to the literature 
is its emphasis on proposing a parsimonious but important set of factors that help to understand the impact of student volunteerism programmes that are most useful and important to the success and sustainability of student volunteerism. Combining volunteering with international travel, cultural exchange and learning objectives, student volunteerism can educate volunteer students and build relationships of understanding between diverse people and places (Hammersley, 2014).

The use of the student volunteerism framework allows one to critically assess the nature of student volunteerism programmes much like any other form of international volunteerism (Sin, 2009). In terms of practical applications of the research, our findings suggest six areas where module design can influence the depth of student orientation, and hence contribute to optimising the eventual university contribution to those local communities (see Table 2). These six factors identified in Table 4 and Figure 2 are potentially applicable to universities considering to initiate these kinds of student volunteerism programmes. Alternatively, academics already running such programmes can use it to evaluate those activities, or to articulate how the courses they offer orient students to maximise the local contributions they make (of use for students considering choices for minors). Likewise, potential and actual host organisations may use it to estimate the value of the benefits they will get with reference to the way the programme is organised and their freedom to co-determine activities.

\section{References}

Barbieri, C., Santos, C.A. \& Katsube, Y. (2012). Volunteer Tourism: On-the-ground Observations from Rwanda. Tourism Management, 33(3), 509-516.

Barkham, P. (2006). Are these the new colonialists? The Guardian. Retrieved from https://www.theguardian.com/society/2006/aug/18/internationalaidanddevelopm ent.education 
Brodie, J. (2006). Are gappers really the new colonialists? The Guardian. Retrieved from http://www.theguardian.com/travel/2006/aug/26/gapyeartravel.guardiansaturday travelsection?CMP=share_btn_link

Brown, S. (2005). Travelling with a purpose: Understanding the motives and benefits of volunteer vacationers. Current Issues in Tourism, 8(6), 479-496.

Brown, S., \& Morrison, A. M. (2003). Expanding Volunteer Vacation Participation an Exploratory Study on the Mini-Mission Concept. Tourism Recreation Research, 28(3), 73-82.

Callahan, M., \& Thomas, S. (2005). Volunteer tourism: Deconstructing volunteer activities within a dynamic environment. Niche Tourism: Contemporary Issues, Trends, and Cases, 183-200.

Carpenter, J., \& Myers, C.K. (2007). Why Volunteer? Evidence on the Role of Altruism, Reputation, and Incentives, IZA Discussion Paper No. 3021, p. 36.

Chen, L.J., \& Chen, J. (2011). The motivations and expectations of international volunteer tourists: A case study of "Chinese Village Traditions". Tourism Management, 32, 435-442.

Cnaan, R. A., Smith, K. A., Holmes, K., Haski-Leventhal, D., Handy, F., \& Brudney, J. L. (2010). Motivations and benefits of student volunteering: Comparing regular, occasional, and non-volunteers in five countries. Canadian Journal of Nonprofit and Social Economy Research. Vol. 1, No 1, Fall / Autumn 2010, 65 - 81

Coghlan, A., \& Noakes, S. (2012). Towards an Understanding of the Drivers of Commercialization in the Volunteer Tourism Sector, Tourism Recreation Research, 37(2), 123-131.

Gibbons M, Limoges C, Nowotny $\mathrm{H}$, et al. (1994) The new production of knowledge: The dynamics of science and research in contemporary societies. London: Sage.

Guttentag, D. A. (2009). The possible negative impacts of volunteer tourism. International Journal of Tourism Research, 11(6), 537-551.

Guttentag, D. A. (2011). Volunteer Tourism: As Good as It Seems?, Tourism Recreation Research, 36(1), 69-74.

Guttentag, D. A. (2012). Volunteer Tourism has Gone Commercial: The Reasons and the Implications, Tourism Recreation Research, 37(3), 273-275.

Hammersley, L.A. (2014). Volunteer tourism: building effective relationships of understanding. Journal of Sustainable Tourism, 22(6), 855-873. 
Holdsworth, Clare \& Quinn, Jocey. (2010). Student volunteering in English higher education. Studies in Higher Education - STUD HIGH EDUC. 35. 113-127.

Holmes, K., Smith, K. M., Lockstone-Binney, L., \& Baum, T. G. (2010). Developing the dimensions of tourism volunteering. Leisure Sciences, 32(3), 255-268.

Lupoli, C., Morse, W.C., Bailey, C., \& Schelhas, J. (2014). Assessing the impacts of international volunteer tourism in host communities: A new approach to organizing and prioritizing indicators. Journal of Sustainable Tourism, 22, 898921.

Lyons, K., Hanley, J., Wearing, S., \& Neil, J. (2012). Gap year volunteer tourism. Myths of Global Citizenship? Annals of Tourism Research, 39(1), 361-378.

McGehee, N.G. (2014) Volunteer tourism: evolution, issues and futures, Journal of Sustainable Tourism, 22(6), 847-854.

Mcgloin, C., \& Georgeou, N. (2015). "Looks good on your CV”: The sociology of voluntourism recruitment in higher education. Journal of Sociology, 1-15.

Popham, G. (2015). Boom in "voluntourism" sparks concerns over whether the industry is doing good | Reuters. Reuters. Retrieved from http://www.reuters.com/article/2015/06/29/us-travel-volunteers-charitiesidUSKCNOP91AX20150629

Rehberg, W. (2005). Altruistic Individualists: Motivations for International Volunteering Among Young Adults in Switzerland. Voluntas: International Journal of Voluntary and Nonprofit Organizations, 16(2), 109-122.

Sin, H. L. (2009). Volunteer tourism: "Involve me and I will learn"? Annals of Tourism Research, 36(3), 480-501.

Smith, K., \& Holmes, K. (2009). Researching volunteers in Tourism: Going beyond. Annals of Leisure Research, 12(3-4), 403-420.

SSH REB. (2005). Guidelines for Ethical Conduct in Participant Observation. University of Toronto Social Sciences and Humanities Research Ethics Board. http://doi.org/10.1186/1472-6963-9-110

Taplin, J., Dredge, D., \& Scherrer, P. (2014). Monitoring and evaluating volunteer tourism: A review and analytical framework. Journal of Sustainable Tourism, 22, 874-897.

Wearing, S., \& McGehee, N. (2013). Volunteer tourism: A review. Tourism Management, 38, 120-130. 
Zahra, A., \& McGehee, N.G. (2013). Volunteer Tourism: A Host Community Capital Perspective, Annals of Tourism Research, 42, 22-45. 